\title{
Evaluation of equations predicting the net portal appearance of amino acid nitrogen in ruminants
}

\author{
R. Martineau, ${ }^{\star}$ C. Côrtes, † I. Ortigues-Marty,‡ D. R. Ouellet, ${ }^{\star}$ and H. Lapierre ${ }^{\star 1}$ \\ *Dairy and Swine Research and Development Centre, Agriculture and Agri-Food Canada, Sherbrooke, Québec, J1M 0C8, Canada \\ †Département de Productions Animales, Unité de Recherche Systèmes d'Élevage, École Supérieure d'Agriculture d'Angers, Angers, 49007, \\ France \\ ‡Institut National de la Recherche Agronomique, UMR1213 Herbivores, Theix, 63122 St Genès Champanelle, France
}

\section{ABSTRACT}

A better assessment of digestible protein and AA flows is required to improve the predictions of animal performance in ruminants (e.g., growth and yields of milk and milk protein). In that respect, 2 recent metaanalyses were conducted in our laboratory to establish the relationships between net portal appearance of AA nitrogen (NPA-AAN) and dietary characteristics either from the National Research Council (Washington, DC) or Institut National de la Recherche Agronomique (INRA; St Genès Champanelle, France). Three prediction equations were selected from these meta-analyses: one equation based only on $\mathrm{N}$ intake (NI) and 2 equations based on NI, the intake of neutral detergent fiber, plus the dietary concentration of either total digestible nutrients or digestible organic matter. In the current meta-analysis, 2 new equations were developed to predict NPA-AAN from the estimated supply of metabolizable protein (MP) and the protein truly digestible in the intestine (PDI). The reliability of these 5 equations to predict NPA-AAN was evaluated using an independent database. On average, NPA-AAN predictions based on the supply of MP or PDI had the highest coefficient of determination and the lowest root of mean square prediction error and mean and regression biases compared with predictions based on dietary characteristics, suggesting better reliability with the former. No major difference was detected between NPA-AAN predictions based on parameters from the National Research Council or INRA, except that predictions based on MP had the lowest mean and regression biases. In each equation, mean of residual NPA-AAN (observed NPA-AAN minus predicted values) was lowest and negative for sheep compared with dairy cows, suggesting that NPA-AAN were overpredicted in sheep. Many continuous variables biased NPA-AAN predictions based on NI only, but none of the tested variables biased the predictions

Received July 11, 2013.

Accepted November 29, 2013.

${ }^{1}$ Corresponding author: Helene.Lapierre@agr.gc.ca based on the supply of MP or PDI, corroborating the better reliability for the prediction equations based on the supply of digestible protein. Of the tested continuous variables, only the dietary concentration of crude protein $(\mathrm{CP})$ biased NPA-AAN predictions based on NI plus dietary characteristics. The NPA-AAN responses to dietary $\mathrm{CP}$ concentration were overpredicted as dietary CP concentration increased and underpredicted as CP decreased, suggesting that ruminants were more efficient at converting ingested $\mathrm{N}$ into digestible protein when fed low-CP diets compared with high-CP diets.

Key words: portal, amino acid, meta-analysis, ruminant

\section{INTRODUCTION}

Over the last decades, feeding evaluation systems of ruminants have evolved from estimations of protein requirements and supply based on the dietary concentrations of $\mathrm{CP}$ or RDP plus RUP toward more refined models based on the supply of digestible protein (e.g., MP of NRC, 2001) and the protein truly digestible in the intestine (PDI) of Institut National de la Recherche Agronomique (INRA, 2007; INRAtion software, version 4.0; INRA, Paris, France). Estimations of the supply of digestible protein might differ between feeding evaluation systems because of differences in the estimations of rumen protein outflows and intestinal digestibilities. Furthermore, NRC (2001) explicitly adds an endogenous component to the digestible protein flow from the undegraded feed protein and the microbial protein, but INRA (2007) does not. The ability of a feeding evaluation system to accurately predict the supply of digestible protein might be indirectly evaluated by its accuracy to predict a zootechnical performance (e.g., milk yield being one the easiest to measure with precision). Yan et al. (2003) used production data of 838 lactating dairy cows drawn from 12 long-term studies and reported that Australian and French systems had a better prediction of milk yield compared with other systems, including NRC (2001). Indeed, a bet- 
ter prediction of milk yield could be associated with a better prediction of the supply of digestible protein, given that the mammary gland is the primary net user of the absorbed AA in dairy cows (Lapierre et al., 2012). One way to estimate the supply of digestible protein is to measure the net transfer of AA across the portal-drained viscera (PDV; gut, spleen, pancreas, and associated mesenteric fat), acknowledging that this measurement already excludes AA utilization by the PDV (Lapierre et al., 2006). The net portal appearance of AA nitrogen (NPA-AAN) has been related to the intakes of N (NI) and NDF (NDFi) and to the dietary concentration of TDN or digestible OM (dOM) in 2 recent meta-analyses: Martineau et al. (2011) and Côrtes et al. [C. Côrtes, R. Martineau, D. R. Ouellet, D. Sauvant (AgroParisTech INRA, Paris, France), J. Vernet (INRA, Theix, St Genès Champanelle, France), I. Ortigues-Marty, P. Nozière (INRA, Theix, St Genès Champanelle, France), and H. Lapierre; hereafter, Côrtes et al., unpublished data]. The relationship between NPA-AAN and the supply of digestible protein has not been established yet.

Acknowledging that the supply of digestible protein is ultimately driving NPA-AAN and based on the findings of Yan et al. (2003), we hypothesized that (1) predictions of NPA-AAN based on the supply of digestible protein would be more accurate compared with predictions based on dietary characteristics and (2) predictions of NPA-AAN based on INRA (2007) parameters (e.g., dOM and PDI) would be more accurate compared with predictions based on NRC (2001) parameters (e.g., TDN and MP). Therefore, the objectives of this study were first, to develop 2 new equations predicting NPA-AAN based on the supply of MP (MP $\left.\mathbf{M}_{\text {supply }}\right)$ or PDI ( PDI $\left._{\text {supply }}\right)$; second, to evaluate and compare these 2 prediction equations based on the supply of digestible protein with the 3 equations based on dietary characteristics; and finally, to examine if systematic biases were influencing NPA-AAN predictions.

\section{MATERIALS AND METHODS}

\section{Equations Predicting NPA-AAN}

All equations tested in the current study were developed by meta-analysis using the same database, hereafter referred to as the development database, and the methodology outlined in Martineau et al. (2011). The reference list of studies used in the development database is reported in the Supplemental Reference List (http://dx.doi.org/10.3168/jds.2013-7249). Briefly, the chemical composition (CP, NDF, and ash) of each feed ingredient was used when reported; if missing, table values from the library of each feed evaluation system were used to yield the value reported for the experimental diet. Nitrogen intake and dietary concentration of $\mathrm{CP}$ were reported in all studies; however, dietary concentrations of NDF and ash were reported in less than half the studies (Martineau et al., 2011). To account for the difference in BW of species in the database [i.e., sheep, cattle, and dairy cows; see Martineau et al. (2011) for description of species], NPA-AAN was reported on a BW basis, as nutrient digestion and absorption have been shown to be similar between sheep and cattle when expressed as a function of $\mathrm{BW}^{1.0}$ (Vernet et al., 2005; Sauvant et al., 2006). Further details on the inclusion criteria and the methodology used to develop the equations are provided in Martineau et al. (2011).

Among the 5 prediction equations tested in the current study, 3 equations predict NPA-AAN based on dietary characteristics and 2 new equations predict NPA-AAN based on the supply of digestible protein

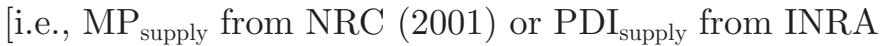
(2007)]. Among the 3 equations that predict NPA-AAN based on dietary characteristics, 1 equation is the simplest prediction of NPA-AAN as a function solely of NI, whereas the other 2 equations are more complex and include the following independent variables: NI plus the ingestion of a fiber factor (i.e., NDFi) and the dietary concentration of an energy factor [i.e., either TDN (NRC, 2001) or dOM (INRA, 2007)]. The 5 equations that predict NPA-AAN are as follows (SE in parentheses and $P$-value in superscript):

$$
\begin{array}{cc}
\text { NPA-AAN }(\mathrm{mg} \text { of N } / \mathrm{d} \text { per } \mathrm{kg} \text { of } \mathrm{BW})= & \\
461^{<0.01}( \pm 54.6) \times \mathrm{NI}-25^{0.49}( \pm 35.6) ; & {[1]} \\
603^{<0.01}( \pm 48.3) \times \mathrm{NI}-5^{0.05}( \pm 2.7) \times \mathrm{NDFi} & \\
+0.3^{0.02}( \pm 0.12) \times \mathrm{TDN}-237^{0.01}( \pm 91.5) ; & {[2]} \\
598^{<0.01}( \pm 59.3) \times \mathrm{NI}-6^{0.07}( \pm 3.1) \times \mathrm{NDFi} & \\
+0.2^{0.08}( \pm 0.10) \times \mathrm{dOM}-167^{0.03}( \pm 76.3) ; & {[3]} \\
0.85^{<0.01}( \pm 0.065) \times \mathrm{MP}_{\text {supply }}-71^{<0.01}( \pm 22.4) ; & {[4]} \\
0.77^{<0.01}( \pm 0.070) \times \mathrm{PDI}_{\text {supply }}-55^{0.04}( \pm 25.7), & {[5]}
\end{array}
$$

where NI and NDFi are in grams per day per kilogram of BW, TDN and dOM are in grams per kilogram of $\mathrm{DM}$, and $\mathrm{MP}_{\text {supply }}$ and $\mathrm{PDI}_{\text {supply }}$ are in milligrams of $\mathrm{N}$ per day per kilogram of BW.

Note that NI is an obligatory covariate in Equations [1] to [3], but NI is not included in Equations [4] and [5]. Tests of significance were conducted on the parameter estimates derived from each species. In Equation [1], 
the slope of NI tended $(P=0.07)$ to be affected by species: $\Delta_{\text {slope }}=130,-91$, and $-38 \mathrm{mg}$ of NPA-AAN/g of NI for sheep, cattle, and dairy cows, respectively; root mean square error $(\mathbf{R M S E})=43 \mathrm{mg}$ of NPA-AAN $/ \mathrm{d}$ per $\mathrm{kg}$ of $\mathrm{BW}$; and $\mathrm{n}=178$ (77 experiments; Côrtes et al., unpublished data). In Equation [2], a species effect was noted on the intercept $(P=0.01): \Delta_{\text {intercept }}$ $=102,-33$, and -68 for sheep, cattle, and dairy cows, respectively; RMSE $=40 \mathrm{mg}$ of NPA-AAN/d per $\mathrm{kg}$ of $\mathrm{BW}$; and $\mathrm{n}=174$ (75 experiments; Martineau et al., 2011). In Equation [3], a species effect was also present on the intercept $(P=0.04): \Delta_{\text {intercept }}=97,-28$, and -68 for sheep, cattle, and dairy cows, respectively; $\mathrm{RMSE}=40 \mathrm{mg}$ of NPA-AAN/d per $\mathrm{kg}$ of BW; and $\mathrm{n}=$ 171 (74 experiments; Côrtes et al., unpublished data). Similarly, a species effect was detected on the intercept $(P<0.01)$ in Equations [4] and [5]. In Equation [4], $\Delta_{\text {in- }}$ tercept $=62,8$, and -70 for sheep, cattle, and dairy cows, respectively; RMSE $=36 \mathrm{mg}$ of NPA-AAN/d per $\mathrm{kg}$ of BW; and $\mathrm{n}=166$ (71 experiments). In Equation [5], $\Delta_{\text {intercept }}=53,-1$, and -52 for sheep, cattle, and dairy cows, respectively; RMSE $=41 \mathrm{mg}$ of NPA-AAN/d per $\mathrm{kg}$ of BW; and $\mathrm{n}=167$ (72 experiments).

\section{Validation Database}

The prediction quality of each equation was evaluated using an independent database, hereafter called the validation database. The reference list of studies used in the validation database is reported in the Sup- plemental Reference List (http://dx.doi.org/10.3168/ jds.2013-7249). Observations in the validation database were selected using the same criteria outlined in Martineau et al. (2011; e.g., exclusion of treatments using metabolism modifiers, infusion, or injection of nitrogenous compounds or VFA). The ration of each observation was reconstituted as outlined in Martineau et al. (2011). The validation database contained 43 observations from studies published before 2009 but not included in Martineau et al. (2011), plus 14 observations from studies published from January 2009 to December 2012. Most observations (71\%) were a single datum from different publications. Note that only data of dairy cows at 4 and 8 wk postpartum from Table 1 in Huntington (1984) were selected; only data of prepartum cows and pooled data ( $\geq 15$ DIM) of control cows from Larsen and Kristensen (2009) and Dalbach et al. (2011), and data of prepartum cows and data of cows fed the ketogenic and the glucogenic diets from Larsen and Kristensen (2012) were selected.

Total NPA-AAN reported on an $\alpha$-amino $\mathrm{N}$ basis ( $\mathrm{n}=28$ of 57 observations) was converted to a total AAN basis by multiplying by 1.3958 to account for the underestimation of total $\mathrm{N}$ when the analytical method is limited to the $\mathrm{N}$ in the $\alpha$-amino group (Martineau et al., 2009). Some adjustments were made to total NPAAAN reported on an individual AA basis when NPA of 1 or more AA was missing: Arg $(\mathrm{n}=13)$, Asn ( $\mathrm{n}$ $=9)$, Pro $(\mathrm{n}=7)$, and Tyr $(\mathrm{n}=1)$. To estimate their contribution to total NPA-AAN, all available observa-

Table 1. Description of net portal appearance of AA nitrogen (NPA-AAN), intake, and dietary characteristics in the development and validation databases ${ }^{1}$

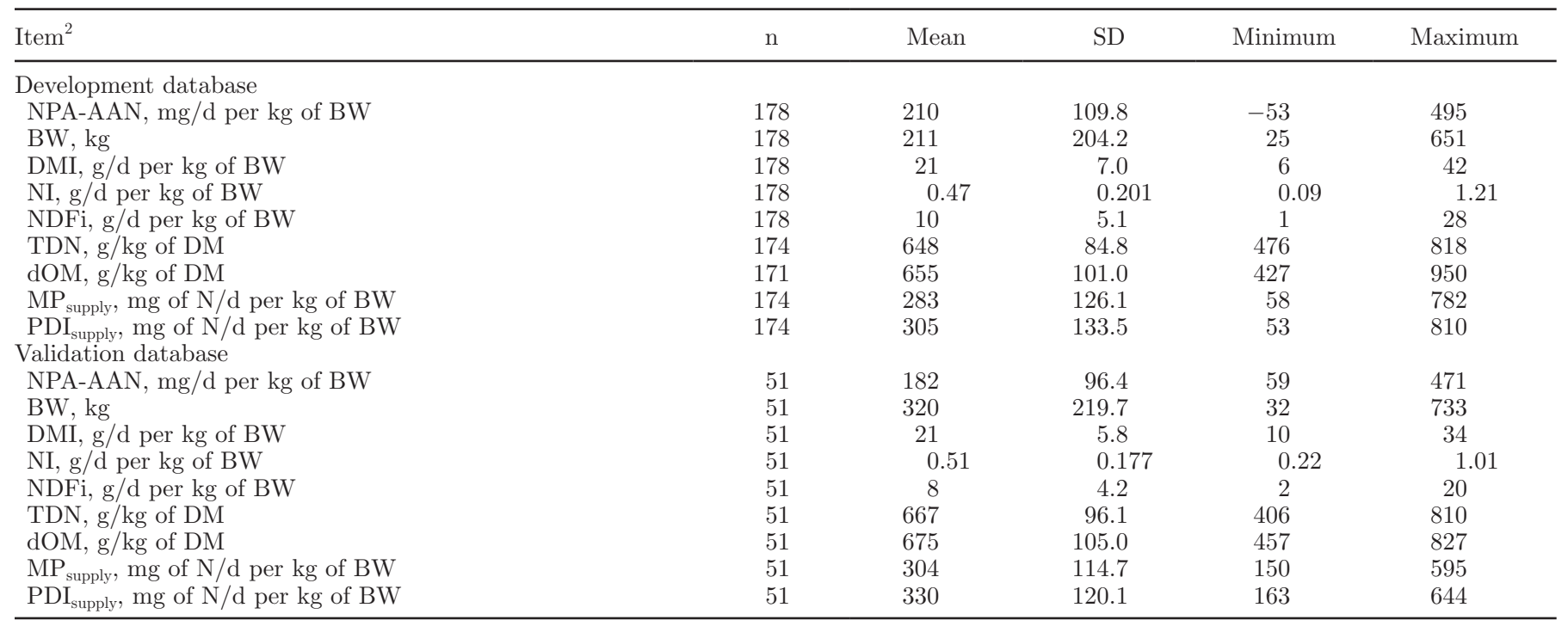

${ }^{1}$ Fifty-nine and 36 publications in the development and validation databases, respectively.

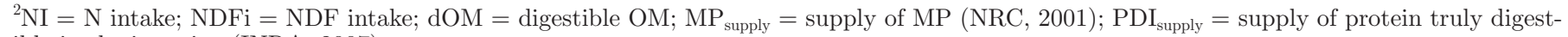
ible in the intestine (INRA, 2007). 
tions in the FLORA database (Vernet and OrtiguesMarty, 2006), where NPA-AAN was reported on an individual basis were used. The contribution of each AA to total NPA-AAN was estimated by regressing (no intercept) the NPA of each AA against the total NPAAAN (both in mg of $\mathrm{N} / \mathrm{d}$ per $\mathrm{kg}$ of $\mathrm{BW}$ ). The slopes for the 4 missing AAN were ( $P$-value in superscript and SE in parentheses) as follows: $0.133^{<0.01}( \pm 0.0038)$, $0.074^{<0.01}( \pm 0.0029), 0.039^{<0.01}( \pm 0.0018)$, and $0.033^{<0.01}$ $( \pm 0.0007)$ for Arg-N (RMSE $=13 \mathrm{mg}$ of NPA-Arg-N/d per $\mathrm{kg}$ of $\mathrm{BW} ; \mathrm{n}=140)$, Asn-N (RMSE $=8 \mathrm{mg}$ of NPA-Asn-N/d per kg of BW; $\mathrm{n}=117$ ), Pro-N (RMSE $=6 \mathrm{mg}$ of NPA-Pro-N/d per $\mathrm{kg}$ of $\mathrm{BW} ; \mathrm{n}=172$ ), and Tyr-N (RMSE $=2 \mathrm{mg}$ of NPA-Tyr-N/d per $\mathrm{kg}$ of BW; $\mathrm{n}=189$ ), respectively. For example, NPA of Arg-N was assumed to be $0.133 \mathrm{mg}$ of $\mathrm{N} / \mathrm{d}$ per $\mathrm{kg}$ of $\mathrm{BW}$ for each incremental $1 \mathrm{mg}$ of total NPA-AAN/d per $\mathrm{kg}$ of BW. The adjusted total NPA-AAN was calculated as NPA-AAN from all reported AA plus the estimated contribution of missing AA.

After NPA-AAN were converted to a total AAN basis and adjusted for missing AA, outliers were identified based on their influence on Cook's distance (Cook, 1979) after successive regressions of observed NPA-

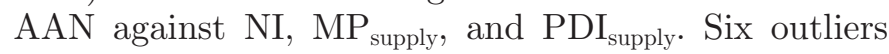
were deleted from the validation database. Descriptive statistics from the development and the validation databases are provided in Table 1.

\section{Statistics}

The effect of species on observed NPA-AAN was determined by the one-way ANOVA and the statistical difference was based on the $95 \%$ confidence interval limits of agreement. Many statistical tests were conducted to assess the reliability of the 5 equations predicting NPA-AAN. The fitting of data (i.e., coefficient of determination) was determined by regression of predicted NPA-AAN against observed values. The amount of agreement between predicted NPA-AAN and observed values was estimated by the concordance correlation coefficient (CCC; Lin, 1989, 1992). The mean square prediction error (MSPE) was computed (i.e., the sum of squared differences between predicted NPA-AAN and observed values divided by the number of observations; Theil, 1966). The positive square root of MSPE (rMSPE) was calculated and expressed in milligrams of NPA-AAN per day per kilogram of BW and expressed as a percentage of the observed mean NPA-AAN (the lower the better). The MSPE was decomposed into 3 error terms according to Bibby and Toutenburg (1977): error in central tendency (ECT) or mean bias, error due to the regression (ER) or linear bias, and error due to disturbance (ED) or random error. The error terms were calculated as follows and expressed as a percentage of MSPE:

$$
\begin{gathered}
\mathrm{ECT}=(\bar{P}-\bar{O})^{2} ; \\
\mathrm{ER}=\left(S D_{P}-\mathrm{r} \times S D_{O}\right)^{2} ; \\
\mathrm{ED}=\left(1-\mathrm{r}^{2}\right) \times S D_{O}{ }^{2},
\end{gathered}
$$

where $\bar{P}$ and $\bar{O}$ are the means, and $S D_{P}$ and $S D_{O}$ are the standard deviations of predicted and observed NPAAAN as calculated by Bibby and Toutenburg (1977), respectively, and $\mathrm{r}$ is the correlation coefficient between predicted and observed values.

Finally, residual NPA-AAN (observed NPA-AAN minus predicted values) were calculated for each prediction equation and used to test if categorical and continuous variables biased NPA-AAN predictions. Two categorical variables [i.e., 3 species (sheep, cattle, and dairy cows) and 2 analytical methods ( $\alpha$-amino- $\mathrm{N}$ and individual AA)] were tested by the one-way ANOVA and the statistical difference was based on the $95 \%$ confidence interval limits of agreement. Eleven continuous variables (i.e., DMI; intakes of TDN, dOM, NFC, and NDF; dietary concentrations of TDN, dOM, NDF, RUP, and CP; and RUP as a proportion of CP) were tested and deemed a bias if the regression of residual NPA-AAN against the continuous variable had a significant $(P \leq 0.05)$ slope. In each regression, the effect of species was tested on the slope and on the intercept.

Residual NPA-AAN biased by a continuous variable can be corrected by adding an adjustment factor expressed as follows: $\mathrm{a} \times(\mathrm{X}-\mathrm{b})$, where $\mathrm{a}$ is the slope of the regression of residual NPA-AAN against the continuous variable, $\mathrm{X}$ are the values of the continuous variable for each observation, and $\mathrm{b}$ (absolute value of intercept/slope of the regression) is the value of the continuous variable where residual NPA-AAN equal zero. Therefore, the adjustment factor yields positive values for $\mathrm{X}>\mathrm{b}$, and vice versa for $\mathrm{X}<\mathrm{b}$, so that adjusted residual NPA-AAN regressed against $\mathrm{X}$ will yield a null intercept and slope.

Because the experimental conditions were not randomly distributed and were specific to each study, experiment and species were considered as fixed factors in the models. The range of inference for this metaanalysis is, therefore, limited to the domain of the specific experiments in the data set (Sauvant et al., 2008). All calculations were performed using Minitab (version 16.2.1.0) or programmed within SAS (SAS Institute, 1998; version 2.0.3) to determine CCC and MSPE analysis. The project was submitted to and approved by the Institutional Committee for Animal Care 
of the Sherbrooke Research Centre (Sherbrooke, QC, Canada), although no animals were required for this study.

\section{RESULTS}

Descriptive characteristics of the development and the validation databases are presented in Table 1 . Note that all data reported for the development database were drawn from Martineau et al. (2011) and from unpublished data, except for $\mathrm{MP}_{\text {supply }}$ and $\mathrm{PDI}_{\text {supply }}$ values (Table 1). The observed NPA-AAN averaged $210( \pm 109.8)$ and $182( \pm 96.4) \mathrm{mg}$ of $\mathrm{N} / \mathrm{d}$ per $\mathrm{kg}$ of $\mathrm{BW}$ in the development $(\mathrm{n}=178)$ and the validation $(\mathrm{n}=$ 51) databases, respectively (Table 1). In both databases, observed NPA-AAN were highest for dairy cows and lowest for cattle. In the development database, observed NPA-AAN averaged ( \pm SE) 229 ( \pm 115.3$)$, $145( \pm 58.1)$, and $288( \pm 104.6) \mathrm{mg}$ of $\mathrm{N} / \mathrm{d}$ per $\mathrm{kg}$ of BW for sheep $(\mathrm{n}=100)$, cattle $(\mathrm{n}=56)$, and dairy cows $(\mathrm{n}=22)$, respectively, and means were different between species based on $95 \%$ confidence interval limits. In the validation database, observed NPA-AAN averaged $203( \pm 50.4), 115( \pm 36.9)$, and $261( \pm 121.3)$ $\mathrm{mg}$ of $\mathrm{N} / \mathrm{d}$ per $\mathrm{kg}$ of $\mathrm{BW}$ for sheep $(\mathrm{n}=14)$, cattle $(\mathrm{n}=22)$, and dairy cows $(\mathrm{n}=15)$, respectively. In the validation database, observed NPA-AAN of sheep and dairy cows were similar and higher compared with observed NPA-AAN of cattle based on $95 \%$ confidence interval limits; in fact, all observed NPA-AAN $\geq 300$ $\mathrm{mg} / \mathrm{d}$ per $\mathrm{kg}$ of $\mathrm{BW}$ were dairy cow data (Figure 1). Mean BW was $34 \%$ lower in the development database compared with that in the validation database. In the development database, mean BW was 49 ( \pm 16.3$)$, 349 $( \pm 76.3)$, and $597( \pm 50.8) \mathrm{kg}$ for sheep, cattle, and dairy cows, respectively. In the validation database, mean BW was $41( \pm 9.3), 309( \pm 76.1)$, and $596( \pm 66.6)$ $\mathrm{kg}$ for sheep, cattle, and dairy cows, respectively. Values of dietary characteristics were similar in both databases but NDFi was $23 \%$ greater in the development database compared with the validation database due to greater dietary concentration of NDF in the former [i.e., $464( \pm 180.9)$ vs. $386( \pm 157.6) \mathrm{g}$ of NDF/ $\mathrm{kg}$ of DM]. In the development database, mean dietary concentration of NDF was $577( \pm 138.5), 299( \pm 123.3)$, and $330( \pm 41.7) \mathrm{g} / \mathrm{kg}$ of DM for sheep, cattle, and dairy cows, respectively. In the validation database, mean dietary concentration of NDF was $517( \pm 84.0)$, $320( \pm 169.0)$, and $324( \pm 87.4) \mathrm{g} / \mathrm{kg}$ of DM for sheep, cattle, and dairy cows, respectively. In both databases, mean dietary concentration of NDF was greater for sheep compared with large ruminants based on the 95\% confidence interval limits. Values of digestible protein supply were similar in both databases. In the development database, mean $\mathrm{MP}_{\text {supply }}$ was $284( \pm 45.6)$, $237( \pm 52.4)$, and $421( \pm 137.6) \mathrm{mg}$ of $\mathrm{N} / \mathrm{kg}$ of $\mathrm{BW}$ for sheep, cattle, and dairy cows, respectively. In the validation database, mean $\mathrm{MP}_{\text {supply }}$ was $266( \pm 100.9)$, $241( \pm 76.7)$, and $518( \pm 133.0) \mathrm{mg}$ of $\mathrm{N} / \mathrm{kg}$ of $\mathrm{BW}$ for sheep, cattle, and dairy cows, respectively. In both databases, mean $\mathrm{MP}_{\text {supply }}$ was greater for dairy cows compared with sheep and cattle based on the $95 \%$ confidence interval limits.

The mean of predicted NPA-AAN was the lowest and the closest to the mean of observed NPA-AAN for Equation [4] based on $\mathrm{MP}_{\text {supply }}$ (188 vs. $182 \mathrm{mg}$ of N/d per $\mathrm{kg}$ of $\mathrm{BW}$; ECT $=1 \%$ of MSPE; Table 2 ). For the regressions of predicted NPA-AAN against observed values, the intercepts and the slopes of Equations [1] to [5] were not different (Table 2). The upper confidence interval limit for the slope of Equations [2] and [3] included $1.0(P<0.05)$, but was smaller than unity for the other equations, which also had a lower standard error. On average, the coefficient of determination was $14 \%$ greater for Equations [1], [4], and [5] compared with Equations [2] and [3]. The CCC was lowest for Equation [2] and similar for the other equations (Table 2 ). Equations [2] and [3] had the highest rMSPE (Table 2 ). The MSPE analysis revealed that ED was the major component of error for all equations (Table 2). Less than $28 \%$ of the error could be attributed to either ECT or ER (or both). The ECT was greatest for Equation [1], whereas ER was greatest for Equations [2] and [3]. Equations [4] and [5] had the lowest ECT and ER.

Categorical and continuous variables were tested on residual NPA-AAN (observed NPA-AAN minus predicted values) to determine if they significantly biased NPA-AAN predictions. In each equation, residual NPA-AAN were lower for sheep compared with dairy cows based on $95 \%$ confidence interval limits. For the 5 equations, residual NPA-AAN averaged $-57,-23$, and $27 \mathrm{mg}$ of $\mathrm{N} / \mathrm{d}$ per $\mathrm{kg}$ of BW for sheep, cattle, and dairy cows, respectively. No difference was detected between AA analytical methods. Several continuous variables were identified as a bias for Equation [1] (Table 3). A positive slope was noted for the energy factors (i.e., TDN, dOM, NFC, and intakes of dOM and NFC), whereas a negative slope was detected for the fiber factors (i.e., NDF and intake of NDF; Table 3). The effect of fiber factors mirrored that of energy factors and both groups of factors were negatively correlated in the validation database $(\mathrm{r}<-0.62 ; P<0.01)$. A positive slope was noted for RUP as a percentage of $\mathrm{CP}$ for Equation [1]. The dietary $\mathrm{CP}$ concentration remained the only significant bias in the predictions after adding fiber and energy factors for Equations [2] and [3] and the slope was negative as for Equation [1]. No bias was detected for Equations [4] and [5] (Table 3). 
Table 2. Parameter estimates of equations predicting the net portal appearance of AA nitrogen (NPA-AAN) from dietary characteristics or from the estimated supply of digestible protein in the validation database

\begin{tabular}{|c|c|c|c|c|c|}
\hline \multirow{2}{*}{ Item $^{1,2}$} & \multicolumn{3}{|c|}{ Dietary characteristics ${ }^{3,4}$} & \multicolumn{2}{|c|}{ Digestible protein supply ${ }^{3,5}$} \\
\hline & Equation [1] & Equation [2] & Equation [3] & Equation [4] & Equation [5] \\
\hline Mean of predicted NPA-AAN & 206 & 205 & 203 & 188 & 198 \\
\hline \multicolumn{6}{|l|}{ Predicted NPA-AAN against observed values } \\
\hline Intercept $( \pm \mathrm{SE})$ & $66( \pm 17.0)$ & $61( \pm 21.5)$ & $57( \pm 20.0)$ & $63( \pm 15.3)$ & $63( \pm 16.0)$ \\
\hline $\mathrm{R}^{2}, \%$ & 64 & 54 & 58 & 63 & 65 \\
\hline $\mathrm{CCC}, \%$ & 77 & 71 & 75 & 79 & 79 \\
\hline \multicolumn{6}{|l|}{ rMSPE } \\
\hline mg of N/d per kilogram of BW & 64 & 76 & 71 & 58 & 60 \\
\hline Percentage of mean observed NPA-AAN & 35 & 42 & 39 & 32 & 33 \\
\hline \multicolumn{6}{|l|}{ MSPE analysis, \% of MSPE } \\
\hline ECT & 13 & 9 & 9 & 1 & 7 \\
\hline
\end{tabular}

${ }^{1}$ Means of predicted and observed NPA-AAN (182) are in milligrams per day per kilogram of BW; intercept, slope, 95\% CI of slope, and $\mathrm{R}^{2}$ are reported for the regression of predicted against observed values.

${ }^{2} \mathrm{CCC}=$ concordance correlation coefficient; rMSPE $=$ root of mean square prediction error (MSPE); ECT = error in central tendency or mean bias; $\mathrm{ER}=$ error due to the regression or linear bias; $\mathrm{ED}=$ error due to disturbance or unexplained error.

${ }^{3}$ Refer to the text for more information on the equations used to predict NPA-AAN.

${ }^{4} \mathrm{NI}=\mathrm{N}$ intake $(\mathrm{g} / \mathrm{d}$ per $\mathrm{kg}$ of $\mathrm{BW}) ; \mathrm{NDFi}=\mathrm{NDF}$ intake $(\mathrm{g} / \mathrm{d}$ per $\mathrm{kg}$ of BW $) ; \mathrm{TDN}=$ dietary concentration of TDN $(\mathrm{g} / \mathrm{kg}$ of $\mathrm{DM}) ; \mathrm{dOM}=$ dietary concentration of digestible $\mathrm{OM}(\mathrm{g} / \mathrm{kg}$ of $\mathrm{DM})$.

${ }^{5} \mathrm{MP}_{\text {supply }}=$ supply of $\mathrm{MP}(\mathrm{mg}$ of $\mathrm{N} / \mathrm{d}$ per $\mathrm{kg}$ of BW $) ; \mathrm{PDI}_{\text {supply }}=$ supply of protein truly digestible in the intestine $(\mathrm{mg}$ of $\mathrm{N} / \mathrm{d}$ per $\mathrm{kg}$ of BW $)$.

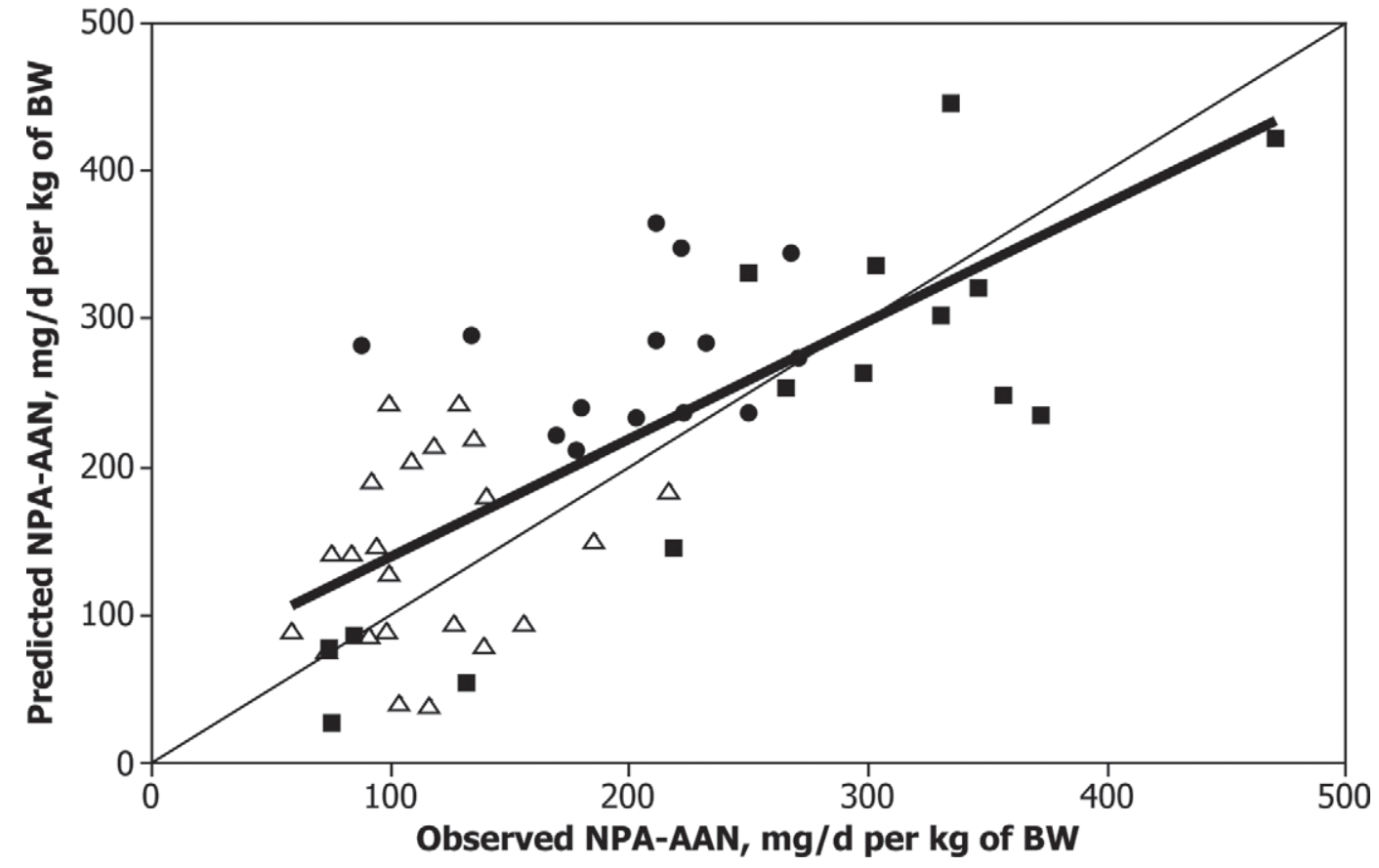

Figure 1. Predicted versus observed net portal appearance of AA nitrogen (NPA-AAN) values for Equation [2] in the validation database (refer to the text for more information on the equation). Mean of predicted NPA-AAN and observed NPA-AAN $=205$ and $182 \mathrm{mg} / \mathrm{d}$ per kg of BW, respectively. - sheep; $\Delta=$ cattle; $=$ dairy cows. Solid line = line of equality; bold line $=$ regression line (refer to Table 2 for the regression equation). 
Table 3. Effect of continuous variables on the residuals (observed minus predicted values) of the net portal appearance of AA nitrogen (NPAAAN) of equations predicting NPA-AAN in the validation database ${ }^{1}$

\begin{tabular}{|c|c|c|c|c|c|}
\hline Item $^{2}$ & \multicolumn{3}{|c|}{ Dietary characteristics ${ }^{3,4}$} & \multicolumn{2}{|c|}{ Digestible protein supply ${ }^{3,5}$} \\
\hline DMI & $-{ }^{6}$ & - & - & - & - \\
\hline TDN & $0.19^{0.03}(9 \%)$ & - & - & - & - \\
\hline $\mathrm{dOM}$ & $0.27^{<0.01}(22 \%)$ & - & - & - & - \\
\hline $\mathrm{TDNi}$ & - & - & - & - & - \\
\hline $\mathrm{dOMi}$ & $4.6^{0.02}(12 \%)$ & - & - & - & - \\
\hline $\mathrm{NFCi}$ & $6.1^{<0.01}(14 \%)$ & - & - & - & - \\
\hline NDFi & $-4.2^{0.04}(9 \%)$ & - & - & - & - \\
\hline RUP & - & - & - & - & - \\
\hline RUP, $\%$ of $\mathrm{CP}$ & $2.5^{0.03}(9 \%)$ & - & - & - & - \\
\hline $\mathrm{CP}$ & $-0.60^{0.05}(8 \%)$ & $-0.98^{<0.01}(14 \%)$ & $-1.10^{<0.01}(20 \%)$ & - & - \\
\hline
\end{tabular}

${ }^{1}$ Residuals of each equation were regressed against each continuous variable; only the slopes of significant $(P \leq 0.05)$ biases are reported $(P$-value of slope in superscript and $\mathrm{R}^{2}$ in parentheses).

${ }^{2}$ Total digestible nutrients, digestible $\mathrm{OM}(\mathrm{dOM})$, NFC, NDF, RUP, and CP are expressed in grams per kilogram of DM, unless indicated otherwise; DMI and TDNi, dOMi, NFCi, and NDFi (intakes of TDN, dOM, NFC, and NDF, respectively) are expressed in grams per day per kilogram of BW.

${ }^{3}$ Refer to the text for more information on the equations used to predict NPA-AAN.

${ }^{4} \mathrm{NI}=\mathrm{N}$ intake $(\mathrm{g} / \mathrm{d}$ per $\mathrm{kg}$ of $\mathrm{BW}) ; \mathrm{NDFi}=\mathrm{NDF}$ intake $(\mathrm{g} / \mathrm{d}$ per $\mathrm{kg}$ of $\mathrm{BW}) ; \mathrm{TDN}=$ dietary concentration of $\mathrm{TDN}(\mathrm{g} / \mathrm{kg}$ of DM); dOM $=$ dietary concentration of $\mathrm{dOM}(\mathrm{g} / \mathrm{kg}$ of $\mathrm{DM})$.

${ }^{5} \mathrm{MP}_{\text {supply }}=$ supply of $\mathrm{MP}(\mathrm{mg}$ of $\mathrm{N} / \mathrm{d}$ per $\mathrm{kg}$ of $\mathrm{BW})$; $\mathrm{PDI}_{\text {supply }}=$ supply of protein truly digestible in the intestine $(\mathrm{mg}$ of $\mathrm{N} / \mathrm{d}$ per $\mathrm{kg}$ of $\mathrm{BW})$.

${ }^{6}-=$ variable is not a significant bias.

A significant $(P<0.01)$ effect of species on the intercept was observed in the regression of residual NPAAAN against dietary $\mathrm{CP}$ concentration for Equations [1], [2], and [3]. Therefore, an adjustment factor was calculated for each species because the intercept is a component of the adjustment factor. As mentioned before, $\mathrm{b}$ delimits the dietary concentration of $\mathrm{CP}$ where residual NPA-AAN equal zero, indicating the threshold between under- versus overprediction of NPA-AAN. The threshold $\mathrm{b}$ of Equations [1], [2], and [3] averaged $83( \pm 21.2), 130( \pm 1.5)$, and $173( \pm 5.3) \mathrm{g}$ of $\mathrm{CP} / \mathrm{kg}$ of DM for sheep, cattle, and dairy cows, respectively; b was lowest for sheep and highest for dairy cows and it was also more variable for sheep compared with large ruminants.

\section{DISCUSSION}

The current study had 2 main objectives: (1) develop 2 new equations predicting NPA-AAN based on the supply of digestible protein and (2) test and compare the reliability of these new prediction equations as well as 3 other prediction equations based on dietary characteristics using statistics such as coefficient of determination, CCC, rMSPE, and MSPE analysis. Another objective was to identify potential biases and evaluate their influence on the predictions. All equations were developed using a large database (i.e., the development database), but the reliability and the effect of potential biases were tested using an independent smaller database (i.e., the validation database).

Parameters from each database were markedly similar and their range of values suggests that the observations covered a wide variety of dietary conditions. Note that sheep was the predominant species in the development database, whereas more large ruminants were recorded in the validation database; the proportion of each species was $0.56,0.31$, and 0.12 versus $0.27,0.43$, and 0.29 for sheep, cattle, and dairy cows in the development versus the validation database, respectively. As a result, a lower mean BW and a greater dietary concentration of NDF were observed in the development database compared with the validation database because sheep were fed diets mostly based on forages. This discrepancy in species between databases should not be a matter of concern because NPA-AAN were predicted on a species basis for each equation in the validation database.

The prediction equations based on dietary characteristics were selected from recent meta-analyses from our laboratory (Martineau et al., 2011; Côrtes et al., unpublished data), but the prediction equations based on the supply of digestible protein were newly developed. Although the prediction equation based on NI 
alone had a high RMSE compared with the other 2 prediction equations based on dietary characteristics, the prediction equation based solely on NI was tested in the current study because NI is considered to be a major driving force in $\mathrm{N}$ metabolism (Castillo et al., 2000; Yan et al., 2006). Besides NI and NDFi, the prediction equations based on dietary characteristics also included an energy factor either from NRC (2001; TDN) or INRA (2007; dOM). Other energy factors from INRA (2007) were considered as potential energy factors [e.g., $\mathrm{OM}$ fermentable in the rumen, calculated from dOM after subtraction of ether extract and RUP $(\mathrm{g} / \mathrm{kg}$, DM basis)]. Although predictions of NPA-AAN could be theoretically improved with the inclusion of OM fermentable in the rumen in the model, this was not the case (Côrtes et al., unpublished data); therefore, dOM was selected as the energy covariate from INRA (2007).

A lack of fit between predicted NPA-AAN and observed values was noticed for each equation, as coefficients of determination ranged from 54 to $65 \%$ (Table 2 ). In addition to errors in the predictions, many factors are known to induce variability across multicatheterization studies (e.g., technical difficulties, differences in AA analytical procedures between laboratories, determinations of plasma flows, analyses run on pooled vs. individual samples, animal variability, and small number of animals per study). Other factors might also affect the accuracy of predictions (e.g., lack of details on feed ingredient or diet composition in many publications). Overall, results from the regression of predicted NPA-AAN against observed values, CCC, and rMSPE suggest that the quality of prediction was better for the 2 prediction equations based on the supply of digestible protein compared with the other prediction equations.

Less than $2 \%$ of the residual error of the prediction equation based on $\mathrm{MP}_{\text {supply }}$ could be attributed to either the mean bias or the regression bias and the slight advantage of the prediction equation based on $\mathrm{MP}_{\text {supply }}$ over that based on PDI $\mathrm{Pupply}_{\text {was }}$ in agreement with the discrepancy in RMSE (i.e., 36 vs. $41 \mathrm{mg}$ of NPA-AAN/d per $\mathrm{kg}$ of $\mathrm{BW}$ for the prediction equations based on $\mathrm{MP}_{\text {supply }}$ and $\mathrm{PDI}_{\text {supply, }}$, respectively). Some factors could explain this slight improvement in accuracy. For instance, $\mathrm{MP}_{\text {supply }}$ is a function of the ration and its estimation involves many parameters [e.g., DMI, in situ parameters, the intestinal digestibility of RUP, the dietary concentration of TDN (itself a function of dietary concentrations of NDF, lignin, ADIN, NDIN, ether extract, and OM), and the TDN discount factor]. On the other hand, $\mathrm{PDI}_{\text {supply }}$ is independent of corrections made to feed parameters and each feed ingredient is characterized by 2 fixed PDI values limited either by the supply of rumen fermentable energy (PDIE) or N (PDIN; INRA, 2007), The supplies of
PDIE and PDIN from each feed ingredient are summed up separately, independent of feed composition and intake, and the lowest total constitutes the dietary PDI supply (Vérité et al., 1979). This straightforward approach does not allow corrections to feed parameters as mentioned before, but this is somewhat compensated by the large selection of feed ingredients with a wide range of PDIE and PDIN values available in the feed library of INRA (2007). For example, for orchard grass (Dactylis glomerata L.) alone, no less than 25, 69, and 46 different types of pasture, silage, and hay, respectively, are included in the feed library of INRA (2007), with PDIE and PDIN values varying from 46 up to 158 $\mathrm{g} / \mathrm{kg}$ of DM.

A striking finding was that the simple prediction equation based on NI alone appeared as good as the prediction equations based on the supply of digestible protein based on coefficient of determination, CCC, and rMSPE values (Table 2). However, several continuous variables biased the predictions of NPA-AAN based on NI, highlighting the importance of taking into account other dietary factors in the prediction equation (Table 3). Moreover, the presence of several biases for the predictions of NPA-AAN based on NI strongly advises against relying only on coefficients of determination, CCC, and rMSPE to compare prediction equations because the prediction equations based on the supply of digestible protein had similar statistics, but no bias, compared with the prediction equation based solely on NI. Therefore, the quality of prediction was better with the equations based on the supply on digestible protein, as corroborated by the MSPE analysis.

Some interpretation can be made on each significant bias according to the direction of the slope. As mentioned before, residual NPA-AAN are calculated as the observed NPA-AAN minus the predicted values (i.e., residual NPA-AAN values increase when observed NPA-AAN > predicted NPA-AAN and vice versa). Therefore, a positive slope indicates that observed NPA-AAN increase but predicted NPA-AAN do not increase as much as observed NPA-AAN as the values of the tested variable on the $\mathrm{x}$-axis increase. In other words, NPA-AAN response is underpredicted as values of the bias increase and overpredicted as they decline, and vice versa for a negative slope.

Overall, results for the equation based on NI alone indicate that NPA-AAN response is underpredicted as dietary energy content increases and overpredicted as it declines, and vice versa for fiber intake. This supports the general concept that, in addition to $\mathrm{N}$ availability, an increased energy supply to the rumen would have an additional positive effect on microbial synthesis and total protein supply to the host (Firkins et al., 2007). Together, these results are in line with Martineau et 
al. (2011), who observed that NPA-AAN responded positively to energy factors (e.g., dietary concentration of TDN) and negatively to fiber factors (e.g., dietary NDF concentration or intake). Furthermore, as for energy factors, NPA-AAN was underpredicted as RUP (\% of $\mathrm{CP}$ ) increased and overpredicted as it declined, suggesting that NPA-AAN responded positively when $\mathrm{CP}$ was less degradable or, conversely, negatively as degradability of CP increased.

In the 3 equations based on dietary characteristics, NPA-AAN response was overpredicted as dietary $\mathrm{CP}$ concentration increased and underpredicted as it declined. This suggests that ruminants are more efficient at converting ingested $\mathrm{N}$ into digestible protein when fed low-CP diets (observed NPA-AAN > predicted values) and less efficient when fed high-CP diets (observed NPA-AAN $<$ predicted values). The $\mathrm{N}$ efficiency when ruminants are fed low-CP diets could be related to the provision of an additional or unaccounted input of $\mathrm{N}$ from urea recycled to the gut (Reynolds and Kristensen, 2008). Those authors reviewed studies in which the urea transferred to the gut was quantified using the dual-labeled urea technique and reported that virtually all of urea entry rate was transferred to the gut lumen in cattle fed low-CP diets $(<12 \%)$. Indeed, the fraction of urea entry used for anabolic purposes was typically greater for such low-CP diets compared with higher protein diets (i.e., 0.28 to 0.72 vs. 0.17 to 0.26 , respectively). Therefore, ruminants have an inherent ability to recycle urea for anabolic purposes when the dietary concentration of $\mathrm{CP}$ is low. The relationship between residual NPA-AAN and the dietary $\mathrm{CP}$ concentration is depicted in Figure 2A for the equation based on NI, NDFi, and TDN. Similar relationships were observed for the equations based solely on NI and based on NI, $\mathrm{NDFi}$, and dOM (data not shown). Figure 2A suggests a loss of $\mathrm{N}$ efficiency with increasing dietary $\mathrm{CP}$ concentration (observed NPA-AAN < predicted values; negative slope), which is apparent for sheep and cattle, but not so much for dairy cows because data are more variable. In dairy cows, 6 out of 7 residual NPA-AAN were positive over $160 \mathrm{~g}$ of $\mathrm{CP} / \mathrm{kg}$ of $\mathrm{DM}$, suggesting a high $\mathrm{N}$ efficiency with high-protein diets in dairy cows. However, from the current data and considering the limited number of observations, it is not clear if this high $\mathrm{N}$ efficiency is a species effect per se or an effect related to nutritional factors that would increase the conversion of NI into digestible protein in dairy cows (e.g., better synchronization of energy and protein, high RUP).

An effect of species $(P<0.01)$ was found on the intercept of the regression of residual NPA-AAN against dietary $\mathrm{CP}$ concentration for each equation based on dietary characteristics. As depicted in Figure 2A, the threshold $\mathrm{b}$ of the adjustment factor was 89,130 , and $177 \mathrm{~g}$ of $\mathrm{CP} / \mathrm{kg}$ of $\mathrm{DM}$ for sheep, cattle, and dairy, respectively. With the inclusion of the adjustment factor on a species basis, residual NPA-AAN are adjusted upward when CP is over the threshold set for each species, and vice versa under it. Adjusted residual NPAAAN regressed against dietary $\mathrm{CP}$ concentration would have a null intercept and slope, with no effect of species on the intercept, as depicted in Figure 2B. Interestingly, dietary $\mathrm{CP}$ concentration was also detected as a systematic bias of predictions based on dietary characteristics across the 77 experiments in the development database. Values of the adjustment factors were similar to those calculated from the validation database. In the development database, the adjustment factor for the prediction equation based on NI, NDFi, and dietary TDN concentration was $1.00 \times(\mathrm{CP}-\mathrm{b})$, where $\mathrm{CP}$ was the mean CP per experiment and b was 108, 147, and $133 \mathrm{~g}$ of $\mathrm{CP} / \mathrm{kg}$ of $\mathrm{DM}$ for sheep, cattle, and dairy cows, respectively. The similarity in results is a supplementary indication that the current study used a sound validation database.

The absence of CP bias for the 2 newly developed prediction equations suggests that the rumen submodels used to estimate the supply of digestible protein are robust to variations in the dietary concentrations of CP. This absence of bias together with favorable statistics (i.e., coefficient of determination, rMSPE, and MSPE analysis) suggest that predictions of NPA-AAN based on the supply of digestible protein are more reliable compared with those based on dietary characteristics, although rumen submodels estimate the supply of digestible protein and AA, but not NPA-AAN per se (Pacheco et al., 2006). In fact, digestible AA will not match NPA of AA because the net utilization of AA by the PDV is not discounted in the digestive flow of AA (Lapierre et al., 2006). The discrepancy between observed NPA-AAN and estimates of digestible protein supply includes losses related to (1) the synthesis and excretion of undigested endogenous protein and (2) the oxidation of some AA by the PDV, either from arterial or luminal supply. In the prediction equations of NPAAAN according to the supply of MP or PDI (i.e., Equations [4] and [5]), these losses are represented in a 2-way fashion: (1) by negative intercepts and (2) by slopes smaller than unity. In theory, the negative intercepts correspond to fixed losses, whereas the slopes smaller than unity indicate additional losses, which increase as the supply of MP or PDI increases. The fixed losses could represent the summation of the metabolic fecal protein plus the basal oxidation of AA. On the other hand, increased losses as the supply of MP or PDI increases would represent a marginal portal recovery rate of intestinal AA supply, which decreases as AA 
A
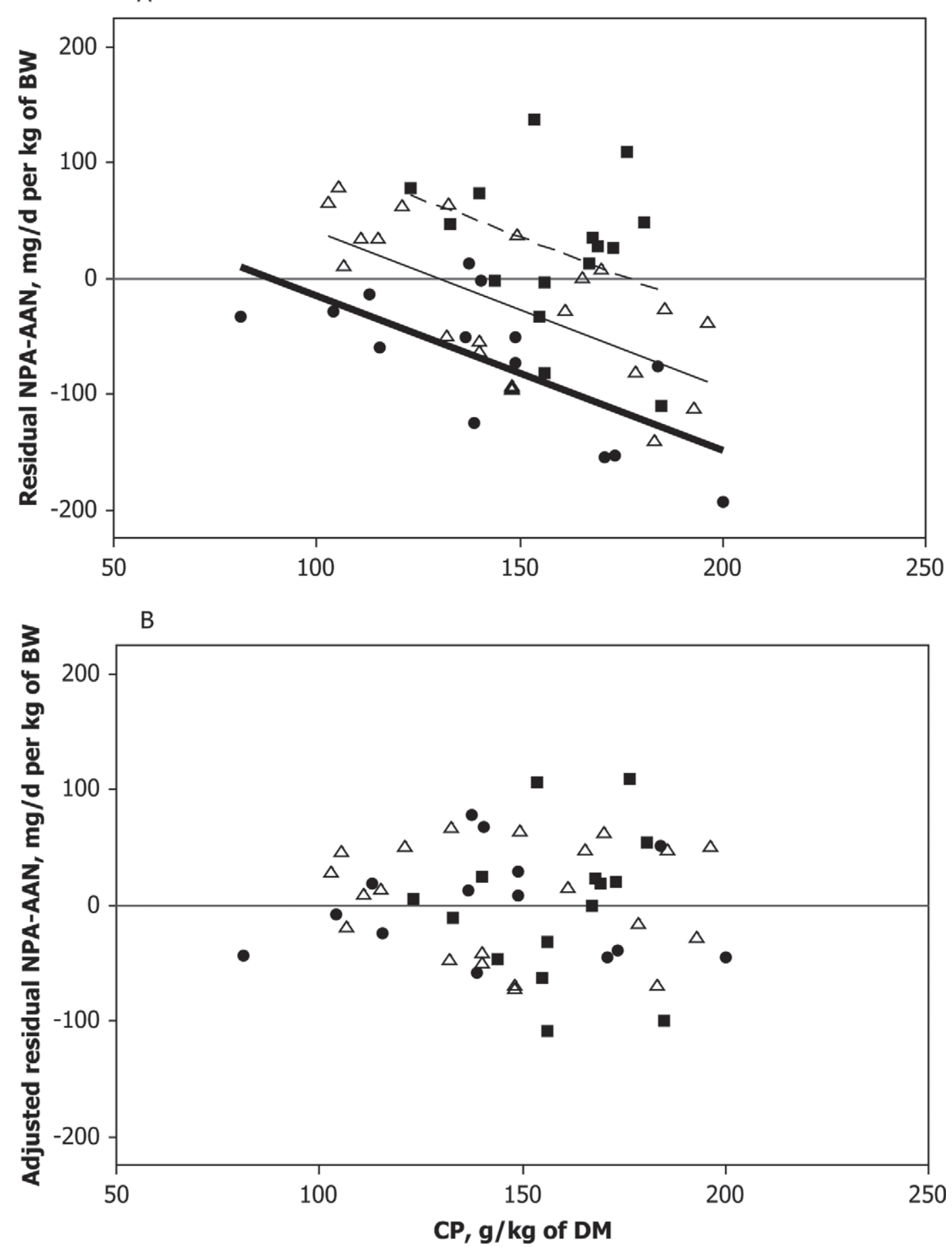

Figure 2. Bias of dietary CP concentration on the residuals (observed minus predicted values) of the net portal appearance of AA nitrogen (NPA-AAN) for Equation [2] in the validation database (refer to text for more information on the equation). Data for sheep (-; bold line), cattle $(\Delta$; solid line), and dairy cows ( $\mathbf{\square}$; dashed line) are shown. (A) Regression of residual NPA-AAN (mg/d per kg of BW) against dietary $\mathrm{CP}$ concentration $(\mathrm{g} / \mathrm{kg}$ of DM; $P$-values as superscripts and SE in parentheses $)=-1.34^{<0.01}( \pm 0.282) \times \mathrm{CP}+177^{<0.01}( \pm 42.8) ; \mathrm{R}^{2}=49 \% ; \mathrm{n}=$ $51 ; \Delta_{\text {intercept }}(P<0.01)=-58,3$, and 60 for sheep, cattle, and dairy cows, respectively. (B) Adjusted residual NPA-AAN $=$ residual NPA-AAN $+1.34 \times(\mathrm{CP}-\mathrm{b})$, where $\mathrm{b}=89,130$, and $177 \mathrm{~g}$ of $\mathrm{CP} / \mathrm{kg}$ of $\mathrm{DM}$ for sheep, cattle, and dairy cows, respectively. 
supply increases. Currently, the fixed losses through metabolic fecal protein losses are only related to DMI (and not to NI) in NRC (2001) and very little data are available about the fixed losses through basal oxidation of AA or direct measurement of AA oxidation across the gut. In sheep, Leu and Met were oxidized by the PDV, but not Lys and Phe (Lobley et al., 2003). In dairy cows, Leu oxidation across the PDV increased with increasing supply of MP (Lapierre et al., 2002). The effect of increased AA losses as the supply of digestible protein increases was examined through portal recovery of AA following duodenal infusion of graded casein levels in sheep (El-Kadi et al., 2006). Based on the regression slopes and the 95\% confidence interval limits, those authors reported that the incremental efficiency of absorption across PDV of branched-chain AA and some nonessential AA (i.e., Gln and Glu) was less than $100 \%$, suggesting that increasing amounts of these AA were catabolized by PDV as the intestinal protein supply increased.

\section{CONCLUSIONS}

The current study showed that the equations predicting NPA-AAN based on the supply of digestible protein from NRC (2001) and INRA (2007) were more reliable compared with those based on dietary characteristics from either feeding evaluation system. None of the tested categorical and continuous variables biased the prediction equations based on the supply of digestible protein, whereas the prediction equations based on dietary characteristics were biased by the dietary concentration of CP. With these latter equations, observed NPA-AAN were higher than predicted values with low-protein diets and vice versa with high-protein diets, especially for sheep and cattle, suggesting that NI is transferred more efficiently into NPA-AAN when the dietary protein is in short supply. No clear difference was detected between feeding evaluation systems, yet mean and regression biases (\% of MSPE) were lowest for the prediction equation based on the supply of MP, suggesting that the rumen submodel of NRC (2001) predicted protein availability slightly more accurately compared with INRA (2007).

\section{ACKNOWLEDGMENTS}

This research was undertaken thanks to funding from Dairy Farmers of Canada (Ottawa, ON, Canada) and Agriculture and Agri-Food Canada (Sherbrooke, QC, Canada).

\section{REFERENCES}

Bibby, J., and H. Toutenburg. 1977. Prediction and improved estimation of linear models. Pages 16-19 in Prediction and Improved Estimation of Linear Models. John Wiley \& Sons, London, UK.
Castillo, A. R., E. Kebreab, D. E. Beever, and J. France. 2000. A review of efficiency of nitrogen utilisation in lactating dairy cows and its relationship with environmental pollution. J. Anim. Feed Sci. $9: 1-32$.

Cook, R. D. 1979. Influential observations in linear regression. J. Am. Stat. Assoc. 74:169-174.

Dalbach, K. F., M. Larsen, B. M. L. Raun, and N. B. Kristensen. 2011. Effects of supplementation with 2-hydroxy-4-(methylthio)butanoic acid isopropyl ester on splanchnic amino acid metabolism and essential amino acid mobilization in postpartum transition Holstein cows. J. Dairy Sci. 94:3913-3927.

El-Kadi, S. W., R. L. Baldwin VI, N. E. Sunny, S. L. Owens, and B. J. Bequette. 2006. Intestinal protein supply alters amino acid, but not glucose, metabolism by the sheep gastrointestinal tract. J. Nutr. 136:1261-1269.

Firkins, J. L., Z. Yu, and M. Morrison. 2007. Ruminal nitrogen metabolism: Perspectives for integration of microbiology and nutrition for dairy. J. Dairy Sci. 90(E. Suppl.):E1-E16.

Huntington, G. B. 1984. Net absorption of glucose and nitrogenous compounds by lactating Holstein cows. J. Dairy Sci. 67:19191927.

INRA (Institut National de la Recherche Agronomique). 2007. INRAtion-Version professionnelle intégrale. 4.0 ed. Educagri éditions, Theix, France.

Lapierre, H., J. P. Blouin, J. F. Bernier, C. K. Reynolds, P. Dubreuil, and G. E. Lobley. 2002. Effect of supply of metabolizable protein on whole body and splanchnic leucine metabolism in lactating dairy cows. J. Dairy Sci. 85:2631-2641.

Lapierre, H., G. E. Lobley, L. Doepel, G. Raggio, H. Rulquin, and S. Lemosquet. 2012. Mammary metabolism of amino acids in dairy cows. J. Anim. Sci. 90:1708-1721.

Lapierre, H., D. Pacheco, R. Berthiaume, D. R. Ouellet, C. Schwab, P. Dubreuil, G. Holtrop, and G. E. Lobley. 2006. What is the true supply of amino acids? J. Dairy. Sci. 89(E. Suppl.):E1-E14.

Larsen, M., and N. B. Kristensen. 2009. Effect of abomasal glucose infusion on splanchnic amino acid metabolism in periparturient dairy cows. J. Dairy Sci. 92:3306-3318.

Larsen, M., and N. B. Kristensen. 2012. Effects of glucogenic and ketogenic feeding strategies on splanchnic glucose and amino acid metabolism in postpartum transition Holstein cows. J. Dairy Sci. 95:5946-5960.

Lin, L. I.-K. 1989. A concordance correlation coefficient to evaluate reproducibility. Biometrics 45:255-268.

Lin, L. I.-K. 1992. Assay validation using the concordance correlation coefficient. Biometrics 48:599-604.

Lobley, G. E., X. Shen, G. Le, D. M. Bremner, E. Milne, A. G. Calder, S. E. Anderson, and N. Dennison. 2003. Oxidation of essential amino acids by the ovine gastrointestinal tract. Br. J. Nutr. 89:617-629.

Martineau, R., I. Ortigues-Marty, J. Vernet, and H. Lapierre. 2009. Technical note: Correction of net portal absorption of nitrogen compounds for differences in methods: First step of a meta-analysis. J. Anim. Sci. 87:3300-3303.

Martineau, R., D. Sauvant, D. R. Ouellet, C. Côrtes, J. Vernet, I. Ortigues-Marty, and H. Lapierre. 2011. Relation of net portal flux of nitrogen compounds with dietary characteristics in ruminants: A meta-analysis approach. J. Dairy Sci. 94:2986-3001.

NRC. 2001. Nutrient Requirements of Dairy Cattle. 7th rev. ed. Natl. Acad. Sci., Washington, DC.

Pacheco, D., C. G. Schwab, R. Berthiaume, G. Raggio, and H. Lapierre. 2006. Comparison of net portal absorption with predicted flow of digestible amino acids: Scope for improving current models? J. Dairy Sci. 89:4747-4757.

Reynolds, C. K., and N. B. Kristensen. 2008. Nitrogen recycling through the gut and the nitrogen economy of ruminants: An asynchronous symbiosis. J. Anim. Sci. 86(E. Suppl.):E293-E305.

SAS Institute. 1998. SAS User's Guide. Version 2.0.3. SAS Institute Inc., Cary, NC.

Sauvant, D., C. Assoumaya, S. Giger-Reverdin, and H. Archimède. 2006. Étude comparative du mode d'expression du niveau d'alimentation chez les ruminants. Congrès 13e Rencontres aut- 
our des Recherches sur les Ruminants. Institut de l'élevage, Paris, France.

Sauvant, D., P. Schmidely, J. J. Daudin, and N. R. St-Pierre. 2008. Meta-analyses of experimental data: Application in animal nutrition. Animal 2:1203-1214.

Theil, H. 1966. Measuring the accuracy of point predictions. Pages 15-36 in Applied Economic Forecasting. North Holland Publishing Co., Amsterdam, the Netherlands.

Vérité, R., M. Journet, and R. Jarrige. 1979. A new system for the protein feeding of ruminants: The PDI system. Livest. Prod. Sci. 6:349-367.

Vernet, J., H. Lapierre, P. Nozière, S. Léger, D. Sauvant, and I. Ortigues-Marty. 2005. Prediction of blood nutrient supply to tissues of economical interest in ruminants: A first step with the prediction of portal blood flow. Pages 163-173 in Open International
Conference on Modeling and Simulation. D. R. C. Hill, V. Barra, and M. K. Traore, ed. Blaise Pascal University, Clermont-Ferrand, France.

Vernet, J., and I. Ortigues-Marty. 2006. Conception and development of a bibliographic database of blood nutrient fluxes across organs and tissues in ruminants: Data gathering and management prior to meta-analysis. Reprod. Nutr. Dev. 46:527-546.

Yan, T., R. E. Agnew, J. J. Murphy, C. P. Ferris, and F. J. Gordon. 2003. Evaluation of different energy feeding systems with production data from lactating dairy cows offered grass silage-based diets. J. Dairy Sci. 86:1415-1428.

Yan, T., J. P. Frost, R. E. Agnew, R. C. Binnie, and C. S. Mayne. 2006. Relationships among manure nitrogen output and dietary and animal factors in lactating dairy cows. J. Dairy Sci. 89:3981-3991. 